\title{
International Reserves and Self-Insurance against External Shocks
}

\author{
Régis Barnichon
}





\title{
IMF Working Paper
}

Policy Development and Review Department

\section{International Reserves and Self-Insurance against External Shocks}

\section{Prepared by Régis Barnichon}

Authorized for distribution by Juan Zalduendo

June 2008

\begin{abstract}
This Working Paper should not be reported as representing the views of the IMF. The views expressed in this Working Paper are those of the author(s) and do not necessarily represent those of the IMF or IMF policy. Working Papers describe research in progress by the author(s) and are published to elicit comments and to further debate.
\end{abstract}

This paper develops an analytical framework that helps to quantify the optimal level of international reserves for a small open economy with limited access to foreign capital and subject to natural disasters or terms of trade shocks. International reserves allow the country to relieve balance of payments pressures caused by external shocks and to avoid large fluctuations in imports. I calibrate the model to two regions, the Caribbean and the Sahel, and assess the sensitivity of the results.

14B

JEL Classification Numbers:F30

Keywords: Foreign Exchange Reserves, Natural Disasters, Terms of Trade Shocks

Author's E-Mail Address:ㅁ.o.barnichon@1se.ac.uk 


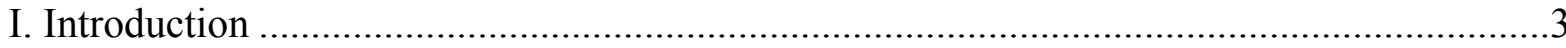

II. Natural Disasters in the Caribbean and the Sahel .....................................................4

A. Hurricanes in the Caribbean................................................................................

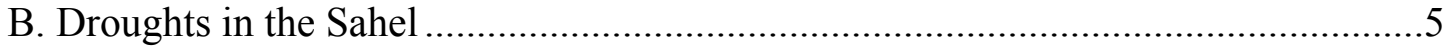

III. A model of optimal international reserves ............................................................6

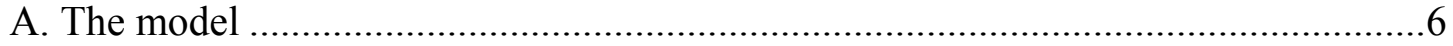

B. An approximated closed-form solution for the reserves-to-imports ratio:................ 8

IV. Calibration and Numerical Solution ...................................................................

A. Self-insurance against natural disasters ........................................................ 10

B. Self-insurance against terms of trade shocks ................................................... 11

C. Self-insurance against natural disasters and terms of trade shocks.......................12

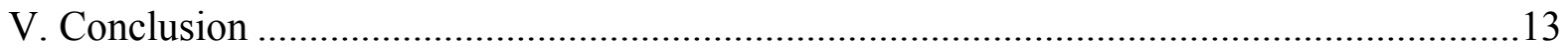

Appendix 1. List of Countries in Each Group ..........................................................21

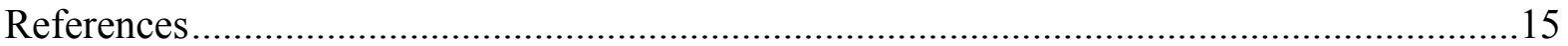




\section{INTRODUCTION}

What is the optimal amount of international reserves for countries with limited access to foreign capital? While the recent build-up in international reserves in Asia spawned a renewed interest in the appropriate level of reserves for emerging market economies, less developed countries have largely been ignored by the literature. As a result, policy makers rely on personal judgment or rules of thumb to evaluate a country's needs.

In this paper, I develop an analytical framework that helps to quantify the level of reserves that can be rationalized in terms of insurance against large external shocks, such as natural disasters or terms of trade shocks. By calibrating the model, I estimate the optimal amount of international reserves for two groups of countries subject to different natural disasters: hurricanes in the Caribbean and droughts in the Sahel.

While there are a number of reasons to accumulate international reserves, many low- to middle income countries have weakly diversified economies that are very vulnerable to natural disasters or terms of trade shocks. Indeed, less developed countries often rely on international trade to import large quantities of goods of prime necessity (such as food) and on a single export sector to generate most of the foreign-exchange inflows. In addition, and unlike middle- to high-income countries, they do not have fast access to private foreign capital and must rely on international and bilateral donors to meet emergency financing needs. Their reliance on such flows, however, has considerable disadvantages. It can take time before donor resources are committed and disbursed, and there may be competition for donor resources from other countries with relief needs at the same time. In this context, international reserves can play a critical role by allowing a rapid access to foreign exchange to avoid large imports fluctuations due to balance of payment constraints.

In this paper, I present a simple model that helps to quantify the level of reserves that can be rationalized in terms of insurance against large external shocks. The model looks at the intertemporal optimization problem of a small open economy that can hold costly foreign reserves to smooth import fluctuations in the face of large external disturbances. Because of the balance of payment constraint, a country can only buy imports if it receives enough foreign exchange inflow. By suddenly disrupting the normal inflow of foreign exchange, a natural disaster or a terms of trade shock may prevent a country from importing the desired level of foreign goods, resulting in a welfare loss. With an appropriate amount of international reserves, a country can minimize the negative impact of such shocks. Under a few simplifying assumptions, I derive a closed form solution for the optimal reserves-toimport ratio that depend on the frequency and duration of shocks, the economic damage, the economy's characteristics and the opportunity cost of holding reserves. Using data on natural disasters and terms of trade shocks since 1960, I calibrate the model and estimate the optimal amount of international reserves for two groups of country: the Caribbean and the Sahel.

The main conclusion of this exercise is that the optimal reserves level is very sensitive to the parameters calibration. Small changes in key parameters such as the shock's persistence, the size of the export sector, or the degree of risk aversion can have large consequences on the optimal reserves level. While an average Caribbean country only needs 1.8 months of import, 
an average Sahel country needs just over 4 months. Hence, rules of thumb can only give an imprecise benchmark, and a careful study of each country's characteristics is necessary to evaluate one country's needs.

It is important to stress however that these estimates constitute only a lower bound on the appropriate reserves level as countries may need to accumulate reserves to achieve objectives other than self-insurance against external shocks. Providing liquidity when needed, limiting exchange rate volatility (or maintaining a fixed-peg) or pursuing an export-led growth by artificially maintaining an undervalued exchange rate are all perfectly good reasons that this framework will brush aside.

The recent build-up in international reserves in Asia spawned a renewed interest in the optimal level of reserves for emerging market countries prone to sudden-stops in capital inflows. Jeanne and Ranciere (2006), Aizeman and Lee (2005) and Caballero and Panageas (2007) present models of optimal international reserves for countries subject to sudden-stops. However, less developed countries have largely been ignored by the literature given their limited access to foreign private capital. An exception is Aslam and Kim (2007) who study the optimal amount of precautionary savings in the face of volatile aid flows. My model is closest in spirit to Jeanne and Ranciere (2006) but with two main differences. The framework is explicitly dynamic, i.e. a country can face more than one external shock over time, and I model the balance of payment constraint faced by low- to middle income countries.

The remainder of the paper is organized as follows. Section II describes the natural disasters hitting countries in the Caribbean and the Sahel and their economic consequences; Section III presents a model of self-insurance against large disruptions in foreign exchange earnings; Section IV calibrates the model and conducts some sensitivity analysis; and Section V offers some concluding remarks.

\section{Natural Disasters in the Caribbean AND THe SAHEL}

While less developed countries tend to have heavily concentrated economies that are vulnerable to terms of trade shocks, many of these countries face an additional challenge because of their geographical location. Figure 1 and 2 display the number of people affected by natural disasters over 1963-2007 for two regions: the Caribbean and the Sahel in SubSaharan Africa. ${ }^{1}$ While the former is regularly hit by hurricanes, the latter suffers frequently from droughts. By disrupting the export sector and the normal inflow of foreign exchange, natural disasters can trigger balance of payments constraints in the same way that terms of trade shocks do. In this section, I will estimate the economic impact of natural disasters in each region, and calculate the average behavior of real output growth, real export growth,

\footnotetext{
${ }^{1}$ Data on natural disasters are drawn from EMDAT, published by CRED (www.em-dat.net).
} 
real import growth and change in the nominal exchange rate in a five-year event window centered on a shock. ${ }^{2}$

\section{A. Hurricanes in the Caribbean}

In September 2004, a Category 3 hurricane hit the island of Grenada and caused an estimated damage over US\$800 million - or twice Grenada's GDP. Just as it required additional resources to finance relief, cleanup and emergency rehabilitations, the island experienced a dramatic decline in revenues and export earnings. Tourism and agriculture, the two major sources of foreign exchange earnings were hit hard. Most tourism facilities could not reopen least the next six months, while the nutmeg plantation, the principal export commodity, was largely destroyed. The government sought donor assistance but despite over US\$150 million in pledges, only US\$12 million was available to address the immediate liquidity needs. Instead of focusing on recovery and reconstruction, the government was distracted by the need to finance the emerging resource gap. This led to delays in the recovery and reconstruction periods. ${ }^{3}$

This episode illustrates the fate of many island nations from the Caribbean who suffer regularly from hurricanes with enormous costs to the stock of capital and disruptions to the productive apparels. Figure 3 present the estimated economic impact of major hurricanes in the Caribbean. On average, a major hurricane hits a Caribbean country every 25 years, i.e. with a probability $\pi^{\text {nd }}=0.96$ each year. ${ }^{4}$ Output growth falls by 3 percentage points while exports fall by 5 percentage points. Despite the shortfall in foreign-exchange earnings, imports do not decline; in fact, the country's import needs for reconstruction purposes are particularly large. As a result, import growth is relatively stable, declining by an average of only 1 percent, while reserves-to-imports ratio growth declines by an average of 16 percent.

\section{B. Droughts in the Sahel}

Figure 4 present the estimated economic impact of major droughts in the Sahel region. An average country from the Sahel region faces one major drought every 12 years, i.e. with a

\footnotetext{
${ }^{2}$ A good proxy for a hurricane's strength is the destruction of capital that it generates. I define hurricanes as "major" when the estimated damage amounts (reported in EMDAT) represent more than 5 percent of a country's GDP. Droughts do not generate direct damage but rather hurt the population by disrupting production and/or triggering episodes of famine. Hence, I classify a drought as "major" when either 10 percent of the population is affected $o r$ when at least four droughts occurred during the year. These thresholds allow me to capture most natural disasters with major consequences while ignoring smaller and more localized disasters that only had a minor impact on production and exports. All my results are robust to alternative thresholds.

${ }^{3}$ Despite the fact that many Caribbean islands are not strictly speaking low-income countries and have theoretically access to international capital markets, their high debt level limits their ability to access credit in the aftermath of a disaster. In addition, access to catastrophe insurance is limited due to the high transaction costs resulting from the relatively small amount of business island nations bring to these markets.

${ }^{4}$ Because natural disasters data are only available at an annual frequency, I cannot use this dataset to estimate the disasters duration.
} 
probability $\pi^{n d}=0.92$ each year. Unlike hurricanes, droughts tend to develop over the course of several years. While the behavior of real economic variables resembles qualitatively that of Caribbean countries, there are quantitative differences. Output growth drops only marginally by 0.3 percentage points on impact before rebounding the next year but exports growth drops by 8 percentage points. Imports remain roughly constant while the reserves-to-imports ratio growth rate falls by 17 percentage points.

\section{A MODEL OF OPTIMAL INTERNATIONAL RESERVES}

In this section, I present and calibrate a simple model of a small open economy that can hold costly international reserves to smooth consumption fluctuations in the face of large terms of trade shocks or large disturbances to exports. Because of the balance of payment constraint, a country can buy imports only if it receives enough foreign exchange inflow. More specifically, a country can import foreign goods by (i) exporting home goods, (ii) borrowing or receiving grants from abroad, and (iii) using foreign exchange reserves. By suddenly disrupting exports and the normal inflow of foreign exchange, a natural disaster or a terms of trade shock may prevent a country from importing the desired level of foreign goods, resulting in a welfare loss. By holding an appropriate amount of international reserves, a country can minimize the negative impact of such shocks. ${ }^{5}$ However, this self-insurance comes at a price because of the opportunity cost of accumulating low-yield securities such as US government bonds.

\section{A. The model}

There are two countries, Home and Foreign. Home is a small open economy consisting of a representative agent that consumes two types of goods: home goods $c_{H}$ and foreign goods $c_{F}$. Both goods are not storable. At each period $t$, the Home consumer receives an endowment $Y_{t}$ of home goods that can either be consumed or exported. I assume that the country exports a fraction $\delta$ of its output. In order to import foreign foods, Home must pay in foreign currency so that at each date $t$, it must satisfy the balance of payments constraint

$$
c_{F, t} \leq \varepsilon_{t} c_{F, t}^{*}-\left(R_{t+1}-R_{t}\right)+\operatorname{Tr}_{t}
$$

where $c_{F, t}^{*}$ is the consumption of home goods by Foreign (i.e. exports of Home), $\varepsilon_{t}$ the real exchange rate, $R_{t}$ is the amount of international reserves and $T r_{t}$ is a generic term for foreign transfers (private remittances or official grants) and loans.

Holding low-yield reserves presents an opportunity cost to Home that I model as a payment $r R_{t}$, payable in home goods. Hence, the aggregate resource constraint takes the form

\footnotetext{
${ }^{5}$ Middle- to high-income countries can address the immediate liquidity needs by borrowing abroad but this is not the case for less developed countries with no immediate access to private foreign capital.
} 


$$
c_{H, t}+\frac{1}{\varepsilon} c_{F, t}=Y_{t}-\frac{1}{\varepsilon}\left(r R_{t}+\left(R_{t+1}-R_{t}\right)-T r_{t}\right)
$$

The representative agent seeks to maximize its expected utility by consuming home and foreign goods subject to the aggregate resource constraint and the balance of payment constraint. At date 0 , Home's problem can be written

$$
\begin{aligned}
& \max _{\left\{c_{H, t}, c_{F, t}\right\}} E_{0} \sum_{t=0}^{\infty} \beta^{t} u\left(c_{H, t}, c_{F, t}\right) \\
& \text { s.t. }\left\{\begin{array}{l}
c_{H, t}+\frac{1}{\varepsilon} c_{F, t}=Y_{t}-\frac{1}{\varepsilon}\left(r R_{t}+\left(R_{t+1}-R_{t}\right)-T r_{t}\right) \\
c_{F, t} \leq \varepsilon c_{F, t}^{*}-\left(R_{t+1}-R_{t}\right)+T r_{t}
\end{array}\right.
\end{aligned}
$$

To capture the occurrence of rare disasters and their impact on the economy, the country's endowments of Home goods as well as the value of its exports follow a two-state Markov process with time-invariant transition probabilities. In a "normal" state, the representative agent receives an endowment $Y^{n}$ and exports a fraction of output $c_{F}^{*_{n}}=\delta Y^{n}$. However, with probability $\pi^{\text {nd }}$, a natural disaster hits the economy in a "normal" state and disrupts output production, exports capacities, and the real exchange rate such that $Y^{d}=\eta_{Y} Y^{n}, c_{F}^{* d}=\eta_{X} c_{F}^{* n}$ and $\varepsilon^{d}=\eta_{\varepsilon} \varepsilon^{n}$ with $\eta_{Y}, \eta_{X}, \eta_{\varepsilon}<1$. Once in a "disaster" state, the economy returns to its "normal" state with probability $\pi^{d n}$ so that $\frac{1}{\pi^{d n}}$ is the expected duration of the disaster.

Since foreign donors typically decide unilaterally on the aid amount they provide to less developed countries, I assume that Foreign provides an exogenous and constant stream of aid $\operatorname{Tr}_{t}$ each period. Hence, in the aftermath of a disaster, Home can only cover its foreign exchange losses by using international reserves. ${ }^{6}$ By denoting $\widetilde{c}_{F, t}=c_{F, t}-T r_{t}$ the imports that are only paid for with international reserves or the proceeds of exports, I can rewrite Home's problem at date $t$ as follows:

$$
\begin{aligned}
& V\left(R_{t}\right)=\max _{R_{t+1}}\left[u\left(c_{H, t}, \widetilde{c}_{F, t}\right)+E_{t} \beta V\left(R_{t+1}\right)\right] \\
& \text { s.t. }\left\{\begin{array}{l}
c_{H, t}=Y_{t}-\delta Y_{t}-r R_{t} \\
\widetilde{c}_{F, t} \leq \varepsilon_{t} \delta_{t} Y_{t}-R_{t+1}+R_{t}
\end{array}\right.
\end{aligned}
$$

\footnotetext{
${ }^{6}$ This assumption remains valid for a time horizon of a few months after the shock. While the IMF, the World Bank and bilateral donors do provide emergency assistance for countries hit by natural disasters, the process can be lengthy, and the funds are usually not available until a few months after the shock.
} 
Home will choose it s level of international reserves to satisfy the first-order condition $u_{C_{F}, t}^{\prime}=\beta E_{t}\left(u_{C_{F}, t+1}^{\prime}-r u_{C_{H}, t+1}^{\prime}\right)$. By accumulating one more unit of reserves in period $t$, Home gives up on consumption of foreign goods at $t$ and of home goods at $t+1$ because of the opportunity cost of reserves, but it also enjoys a higher expected utility of foreign goods consumption at $t+1$.

In the steady-state of the "normal" state, Home reaches its optimal reserves level $R^{*}$ and its consumptions of home and foreign goods are

$$
\left\{\begin{array}{l}
c_{H}=Y^{n}-\delta Y^{n}-r R^{*} \\
c_{F}=\varepsilon \delta Y^{n}+T r
\end{array}\right.
$$

\section{B. An approximated closed-form solution for the reserves-to-imports ratio:}

In this subsection, I simplify the algebra by using the log-utility specification

with $\theta \in[0,1]$.

$$
u\left(c_{H, t}, c_{F, t}\right)=\theta \ln \left(c_{H, t}\right)+(1-\theta) \ln \left(c_{F, t}\right)
$$

When shocks are rare and have little persistence, one can show that it is optimal for Home to use all of its reserves at once when a shock hits. In that case, one can derive an approximated closed-form solution for the optimal reserves to imports ratio

$$
\frac{R^{*}}{c_{F}} \approx\left[\frac{\beta \pi^{n d}}{\beta r\left(1-\pi^{n d}\right) \frac{\varepsilon \delta}{1-\delta}+\left(1-\beta\left(1-\pi^{n d}\right)\right) \frac{1-\theta}{\theta}}-\eta_{X} \eta_{\varepsilon}\right] \frac{1}{1+\frac{T r}{\varepsilon \delta Y^{n}}}
$$

by using the fact that $r<<1$.

Looking at equation (2), one can draw a number of intuitive conclusions on the determinant of the optimal amount of reserves. A higher shock probability (i.e. a higher $\pi^{\text {nd }}$ ), a larger drop in the value of exports (i.e. a higher $\eta_{X}$ or $\eta_{\varepsilon}$ ) or a larger export sector (i.e. a higher $\delta$ ) raises the optimal reserves-to-import ratio. On the other hand, a higher opportunity cost of holding reserves (i.e. a higher $r$ ) lowers the reserves-to-import ratio. Finally, the share of imports covered by foreign grants or loans $T r$ influences the level of optimal reserves. A higher level of transfers (official loans or grants, and private remittances) in steady-state lowers the optimal reserves-to-import ratio as transfers or loans are not sensitive to natural disasters. $^{7}$

\footnotetext{
${ }^{7}$ Again, a higher level of aid in the immediate aftermath of a disaster would lower the optimal reserve level even further. However, as I argued in previous footnote, a rapid response on a large scale is unlikely in the first months after the shock.
} 


\section{Calibration ANd Numerical Solution}

In this section, I calibrate the model, calculate the optimal reserves-to-imports ratio and conduct a sensitivity analysis exercise for each groups of countries. ${ }^{8}$

For the calibration, I use the utility function

$$
u\left(c_{H, t}, c_{F, t}\right)=\theta \frac{\left(c_{H, t}-\underline{c}_{H}\right)^{1-\rho}-1}{1-\rho}+(1-\theta) \frac{\left(c_{F, t}-\underline{c}_{F}\right)^{1-\rho}-1}{1-\rho}
$$

with $\rho$ the relative risk aversion parameter, $\theta$ the preference for home goods and $\underline{c}_{H}$ and $\underline{c}_{F}$ the subsistence consumption level of home and foreign goods. This Stone-Geary preference specification will be useful when I calibrate the model to Sub-Saharan African countries whose consumption is close to subsistence levels. ${ }^{9}$

In order to capture the urgency posed by some disasters, I use a monthly frequency for the calibration. Indeed, the main disruptions caused by a natural disaster such as a hurricane and droughts do not happen over the course of a year but over a few weeks or months. Hurricanes are sudden and short-lived events and the shortage of foreign exchange may materialize in the first weeks after the shock, not the next quarter or year. As a result, imports may drop to close to zero in the immediate aftermath of the shock with an arbitrarily large utility loss if a country does not hold any international reserves. A yearly frequency would smooth out the import loss and mask the utility loss given the concavity of the utility function.

The optimal level of reserves depends on 11 parameters; the probability of a disaster and its persistence, determined respectively by $\pi^{n d}$ and $\pi^{d n}$, the output loss $\eta_{Y}$, the exports loss $\eta_{X}$, the exchange rate depreciation $\eta_{\varepsilon}$, the opportunity cost of holding reserves $r$, the coefficient of risk aversion $\rho$ and the preference for Foreign goods $\theta$, the size of the export sector $\delta$ and the subsistence levels of consumption $\underline{c}_{H}$ and $\underline{c}_{F}$. Using the evidence from Section II on the impact of disasters and terms of trade shocks, I can calibrate the parameters of the model and estimate the optimal level of international reserves for countries from the Caribbean and the Sahel region.

Table 1 presents the calibration parameters used for each country group. I set the monthly probability of shocks to match the estimates from Section II, and I fix the output and exports

\footnotetext{
${ }^{8}$ The problem is solved numerically by value function iteration.

${ }^{9}$ This specification is consistent with the evidence from Ogaki and Zhang (2001) and Ogaki, Ostry and Reinhart (1996) that the relative risk aversion coefficient is a decreasing function of wealth in poor countries. The Stone-

Geary utility function (3) implies a relative risk aversion coefficient for foreign goods equal to $\rho \frac{c_{F}}{c_{F}-\underline{c}_{F}}$,
} and the country becomes more risk averse as consumption gets closer to subsistence levels. 
loss parameters to match the empirical ones. The size of the export sector is chosen to match the average exports-to-GDP ratio of the group, and the preference for foreign goods is set accordingly. I set the monthly discount factor $\beta$ to 0.9966 and the coefficient of risk aversion to 5. Unless otherwise noted, I fix the subsistence levels of consumption to zero and the opportunity cost of holding reserves to 0.33 percent per month (or 4 percent a year).

\section{A. Self-insurance against natural disasters}

\section{Hurricanes in the Caribbean}

In a "normal" state, the average Caribbean country exports and imports respectively 30 percent and 40 percent of its output. "Transfers" provide the remaining 10 percent of the financing. Consistent with Section II, a major hurricane hits every 25 years. Given that hurricanes are sudden events with little persistence and maximum disruption in impact, I assume that a natural disaster brings exports to a full stop for some time. To estimate that time, I calculate how many months with zero imports are necessary to match the total exports loss of 10 percent identified in Section II. That way, I estimate that a hurricane disrupts exports for an average of one month and a quarter while output drops by 36 percent. ${ }^{10}$ Given that countries from the Caribbean fixed have exchange-rate regimes in the majority of cases, I keep the real exchange rate constant during disasters.

The optimal level of reserves covers 1.60 months of imports, i.e. slightly more than the expected duration of the disaster. Figure 5 illustrates the sensitivity of the results to key parameters: the return period of disasters (i.e. the disaster's probability), the disaster's persistence, the size of the export sector, the opportunity cost of holding reserves, the subsistence level of imports and the coefficient of risk aversion. In each case, I start from the baseline calibration and vary one parameter at a time to draw a number of conclusions. First, the optimal reserves-to-imports ratio increases with the shocks' probability (or return period) and the shock's persistence. Second, there is an inverse U-shape relationship between the size of the export sector and optimal reserves. This is due to the interaction of two factors: the utility cost of accumulating reserves and the opportunity cost of maintaining a given level of reserves. Given the concavity of the utility function, higher foreign-exchange inflows (i.e. a larger export sector) make reserves accumulation relatively easier, and the optimal reserves-to-import ratio increases. However, above a certain level, the country exports and imports such a large share of its GDP that the steady state level of reserves gets large relative to GDP, and the opportunity cost of holding reserves becomes non-negligible. However, given the small size of the export sector in the baseline calibration, the amount of reserves is small relative to GDP and the opportunity cost of holding reserves has only a small impact on the level of reserves. Third, the optimal reserves-to-import ratio increases with the subsistence level of import and a subsistence level of 10 percent of GDP implies reserves of almost 3 months of import. Finally, optimal reserves increase with the degree of risk aversion.

\footnotetext{
${ }^{10}$ A more realistic assumption would be to assume a gradual recovery phase starting one month after the shock. The present calibration exercise is mostly illustrative but could be easily extended to a richer setting.
} 


\section{Droughts in the Sahel}

The average country from the Sahel region faces one major drought every 12 years. Droughts are more frequent than hurricanes and cause little physical damage but are also more persistent. Accordingly, I assume that annual output growth is unaffected while exports drop by 16 percent for 6 months, consistent with the 8 percent annual decline documented in Section II. The average Sahel country exports and imports respectively 20 percent and 30 percent of its output. Transfers provide the remaining 10 percent of the financing. Since most countries from the Sahel are part of the CFA Franc zone, I keep the real exchange rate constant during disasters. Finally, to capture the situation in Sub-Saharan Africa where most of the population lives close to subsistence levels and where a small drop in consumption can have disastrous consequences, I postulate a non-zero subsistence level of imports. ${ }^{11}$ Indeed, the 2008 riots in Sub-Saharan Africa following the price increase of a number of food products shows that consumption in normal times is very close to subsistence levels. To calibrate $\underline{c}_{F}$, I assume that the 2008 riots were the result of consumption reaching subsistence levels. Using equation (1) and given that the riots were triggered by an increase in food prices of 50 percent in one year and that the food basket represents roughly 40 percent of imports for an average Sahel country, I set the subsistence level of imports at 80 percent of "normal" imports, i.e. 26 percent of "normal" GDP. However, I also present the sensitivity of the results to a range of subsistence levels.

The optimal reserves-to-import ratio is about 2 months. While the shock is less violent than with hurricanes, its duration makes it costly as it brings the population close to subsistence levels (i.e. close to famine levels) for a long time. This provides a strong rational for holding international reserves. When a drought occurs, reserves are used progressively to minimize the decline in imports over the expected duration of the drought. Figure 6 presents the sensitivity analysis for two parameters of interest. In the Sahel, the key determinant of optimal reserves is the subsistence level of imports. As the subsistence level of imports gets closer to the quantity of imports during droughts, the optimal level of reserves increases sharply. Similarly, when the size of the export sector (or the import sector) increases, the optimal reserves-to-import ratio declines as consumption moves away from subsistence levels and droughts become less costly.

\section{B. Self-insurance against terms of trade shocks}

I now consider the impact of terms of trade shocks on the optimal level of international reserves. Caribbean economies tend to be less concentrated than in the Sahel, and the primary sector represents a smaller share of GDP. As a result, Caribbean countries are less sensitive to fluctuations in prices of raw materials, agricultural products and staple. Using data on major terms of trade shocks since1960, I find that while an average Caribbean country faces a ten percent decline in its terms of trade every 17 years with no significant cost to output or

${ }^{11}$ Given the small effect of a drought on exports, the optimal reserves-to-import ratio is close to zero at 0.08 months if the subsistence level of imports is set to zero. 
exports growth, an average Sahel country faces a fifteen percent decline every 10 years with a 5 percent decline in exports growth. ${ }^{12}$

By calibrating the model to these transition probabilities and assuming that a terms of trade shock lasts for a year with no other economic impact on output and exports than the depreciation in $\varepsilon$, I find that the optimal reserves level represents less than 0.01 months of import for a Caribbean country but 2.5 months for a Sahel country. ${ }^{13}$ Again, by bringing consumption of foreign goods close to subsistence levels of for a long time, terms of trade shocks provide a strong rational for holding international reserves in the Sahel. In the Caribbean however, a terms of trade shock lowers imports from 50 percent of GDP to slightly less than 45 percent, a small welfare loss given the concavity of the utility function.

\section{Self-insurance against natural disasters and terms of trade shocks}

I now estimate the optimal reserves-to-import ratio for each region by taking into account the possibility of natural disasters and terms of trade shocks. To do so, I generalize the two-state Markov process from Section III to three states. Home can either be in a "normal" state, facing a terms of trade shock or facing a natural disaster, and the transition probabilities are the ones used previously.

The reserves target represents 1.8 months of import for a Caribbean country, only slightly more than in Subsection A as self-insurance against natural disasters is the main motive for holding international reserves. For a country from the Sahel, however, the optimal reserves level stands at 4.1 months of imports, as droughts and terms of trade shocks are equally important disturbances.

Figure 7a shows the impact of a terms of trade shock and a natural disaster on exports, imports and international reserves in the Caribbean. While Home initially keeps imports close to normal after the terms of trade shock, it progressively slows down the use of its reserves and reduces imports to avoid using too much of foreign exchange. Since the shock lasts much longer than expected (3.5 years instead of 1 year), Home stops using reserves after some time so as to keep enough reserves to respond to a hurricane. After the hurricane, exports drop by 50 percentage points but imports decline by only 10 percentage points thanks to the quick use of international reserves.

Figure $7 \mathrm{~b}$ simulates the evolution of international reserves in a Sahel country. While Caribbean countries face the possibility of large, but rare, disruptive shocks, droughts and terms of trade shocks induce only mild, albeit frequent, declines in foreign exchange inflows. When hit by a terms of trade shock, Caribbean countries still face the possibility of very disruptive shocks and cannot afford to use too much reserves. This is not the case in the

\footnotetext{
${ }^{12}$ I consider a worsening in the terms of trade to be major when it is above 10 percent, based on data drawn from the IMF's World Economic Outlook. I ignore terms of trade shocks that coincide with natural disasters.

${ }^{13}$ These assumptions are consistent with estimates of the economic impact of a terms of trade shock in each region. The empirical analysis (similar to the one conducted in Section II) is available upon request.
} 
Sahel however, and in Figure 7b Home does not progressively slow down the use of its reserves. Similarly while Caribbean countries have to accumulate reserves at a fast pace, Sahel countries can smooth reserves accumulation.

The main conclusion of this exercise is that the optimal reserves level is very sensitive to the parameters calibration. As a result, rules of thumb can only give an imprecise benchmark. While an average Caribbean country only needs 1.8 months of import, an average Sahel country needs 4.1 months. First, small parameter changes can have large consequences on the optimal reserves level. For example, depending on the size of the export sector, the optimal reserves level in the Caribbean can take values between 0 and 2 months of import in the baseline calibration. Similarly, a shock's persistence of 2 months calls for roughly 3 months of imports in reserves but a persistence of 3 months already calls for 5 months. ${ }^{14}$ Second, while some parameters play a critical role in a country, they can be almost irrelevant in another one. For example, the opportunity cost of holding reserves is negligible in a country with a small sector but it becomes determinant when exports represent a large share of GDP. Finally, note that the average reserves level over time can be very different from the optimal level in steady-state, and one cannot evaluate a country's target by simply looking at its historical average. For example, the optimal reserves-to-import ratio is above 4 months for countries from the Sahel but the average reserves level is only at 3.2 months over the 16 years of the simulation.

\section{Conclusion}

In this paper, I develop an analytical framework that helps to quantify the level of reserves that can be rationalized in terms of insurance against large external shocks, such as natural disasters and terms of trade shocks. By calibrating the model, I estimate the optimal amount of international reserves for two groups of countries hit by different natural disasters: hurricanes in the Caribbean and droughts in the Sahel.

The main conclusion is that the optimal reserves level can be very sensitive to the parameters calibration, and the model needs to be carefully calibrated to evaluate one country's needs. Small changes in key parameters such as the size and persistence of shocks hitting a country, the importance of the export sector, or the degree of risk aversion can have large consequences on the optimal reserves level.

\footnotetext{
${ }^{14}$ Note that the persistence of the shock can also be interpreted as the time taken by the international community to intervene and provide assistance that compensates for the loss in foreign exchange inflows.
} 
An interesting extension would be to use a similar framework to evaluate the optimal size of Sovereign Wealth Funds for economies relying mostly on primary commodities. While the income provided by natural resources can provide large foreign exchange inflows, price volatility as well as uncertainty about the exact amount of natural resources available call for the accumulation of a reserves to smooth price fluctuations and to provide an alternative source of revenue. 


\section{REFERENCES}

Aslam A. and J. Kim, 2007, “Aid Volatility and Precautionary Saving,” Working Paper.

Aizenman, J., and J. Lee, 2005, "International Reserves: Precautionary Vs. Mercantilist Views, Theory, and Evidence," IMF Working Paper 05/198 (Washington: International Monetary Fund).

Caballero, R., and S. Panageas, 2007, "A Global Equilibrium Model of Sudden Stops and External Liquidity Management,” unpublished, MIT, Department of Economics.

Jeanne, O., and R. Ranciere, 2006, “The Optimal Level of International Reserves for Emerging Market Countries: Formulas and Applications," IMF Working Paper 06/229 (Washington: International Monetary Fund).

Ogaki, M., D. Ostry and C. Reinhart, 1996, "Saving Behavior in Low- and Middle-Income Developing Countries," IMF Staff Papers, Vol 43-1.

Ogaki, M. and Q. Zhang, 2001, "Decreasing Relative Risk Aversion and Tests of Risk Sharing," Econometrica, Vol 69-2. 
Table 1: Calibration (monthly frequency)

\begin{tabular}{|c|c|c|c|c|c|}
\hline \multirow[b]{2}{*}{$\begin{array}{l}\text { Probability of disaster } \\
\text { (Return period) }\end{array}$} & \multirow[b]{2}{*}{$\pi^{n d}$} & \multicolumn{2}{|c|}{ Caribbean } & \multicolumn{2}{|c|}{ Sahel } \\
\hline & & $\begin{array}{l}\text { Hurricanes } \\
0.33 \% \\
\text { (25 years) }\end{array}$ & $\begin{array}{c}\text { ToT shocks } \\
0.55 \% \\
\text { (17 years) }\end{array}$ & $\begin{array}{l}\text { Droughts } \\
0.66 \% \\
\text { (12 years) }\end{array}$ & $\begin{array}{c}\text { ToT shocks } \\
0.88 \% \\
\text { (10 years) }\end{array}$ \\
\hline $\begin{array}{l}\text { Persistence of disaster } \\
\text { (Duration) }\end{array}$ & $\pi^{d n}$ & $\begin{array}{c}0.83 \% \\
(1.25 \\
\text { months })\end{array}$ & $\begin{array}{c}0.08 \% \\
\text { (1 year) }\end{array}$ & $\begin{array}{c}0.16 \% \\
(6 \text { months) }\end{array}$ & $\begin{array}{l}0.08 \% \\
(1 \text { year })\end{array}$ \\
\hline Output loss & $\eta_{y}$ & $36 \%$ & 0 & $1 \%$ & $0.5 \%$ \\
\hline Exports loss & $\eta_{x}$ & $\begin{array}{c}100 \% \\
(10 \% \text { vearly) }\end{array}$ & 0 & $\begin{array}{c}16 \% \\
\text { ( } 8 \% \text { yearly) }\end{array}$ & $5 \%$ \\
\hline Terms of trade loss & $\eta_{\varepsilon}$ & 0 & $10 \%$ & 0 & $15 \%$ \\
\hline Exports-to-GDP ratio & $\delta$ & 0.4 & 0.4 & 0.2 & 0.2 \\
\hline $\begin{array}{l}\text { Risk Aversion } \\
\text { Subsistence level of }\end{array}$ & $\rho$ & 5 & 5 & 5 & 5 \\
\hline $\begin{array}{l}\text { (in \% of initial GDP) } \\
\text { (imports }\end{array}$ & $\underline{c}_{F}$ & $0 \%$ & $0 \%$ & $26 \%$ & $26 \%$ \\
\hline $\begin{array}{l}\text { Transfers } \\
\text { (in \% of initial GDP) }\end{array}$ & $\operatorname{Tr}$ & $10 \%$ & $10 \%$ & $10 \%$ & $10 \%$ \\
\hline $\begin{array}{l}\text { Optimal Reserves- } \\
\text { to-Imports ratio (in } \\
\text { months of imports) }\end{array}$ & $\frac{R^{*}}{c_{F}}$ & 1.60 & $<0.01$ & 2.05 & 2.46 \\
\hline Shocks combined & & 1.' & & & \\
\hline
\end{tabular}


Figure 1: Total number of people affected by type of natural disaster in the Caribbean region over 1963-2007.

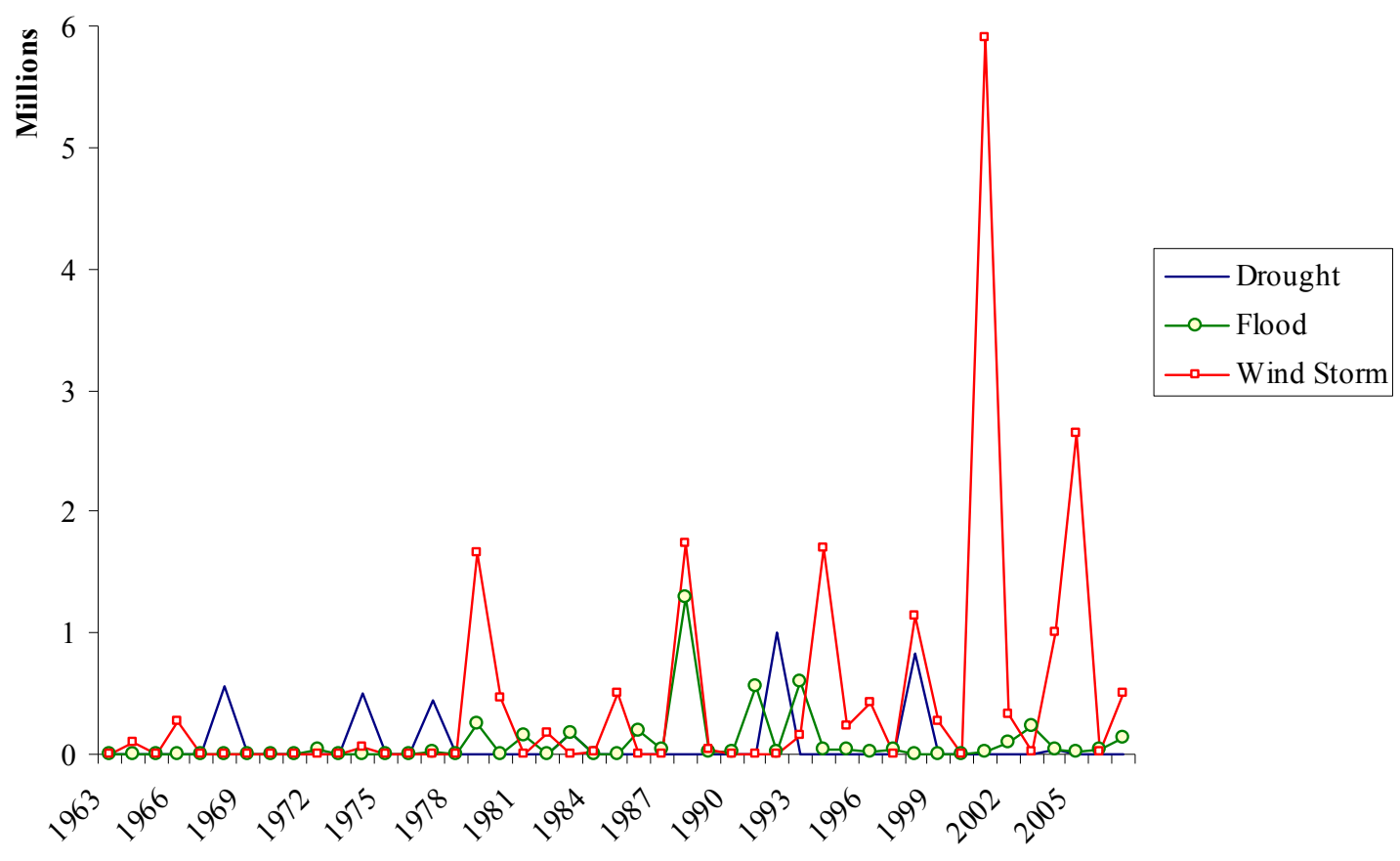

Figure 2: Total number of people affected by type of natural disaster in the Sahel region over $1963-2007$

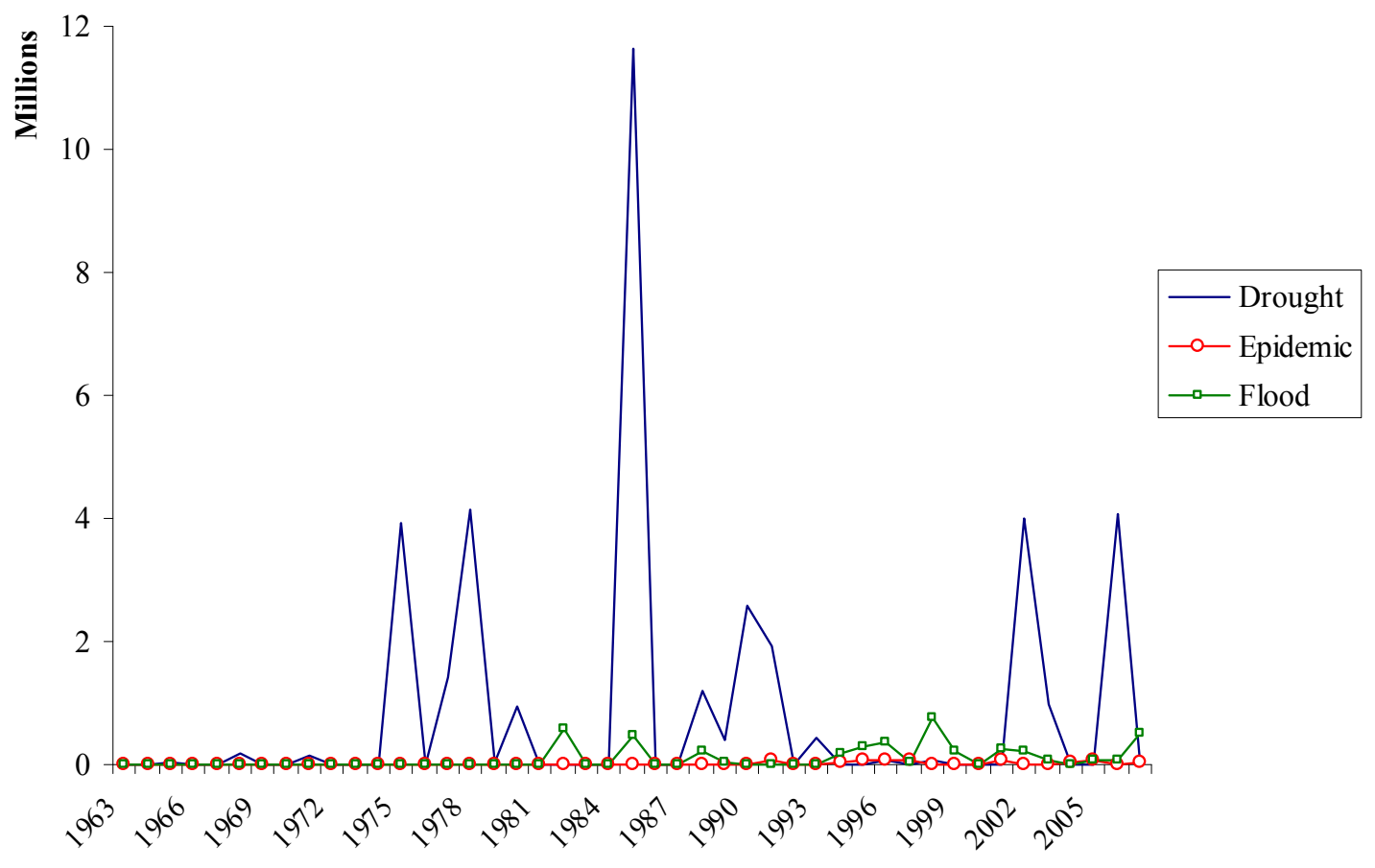


Figure 3: Impact of a Natural Disaster in the Caribbean
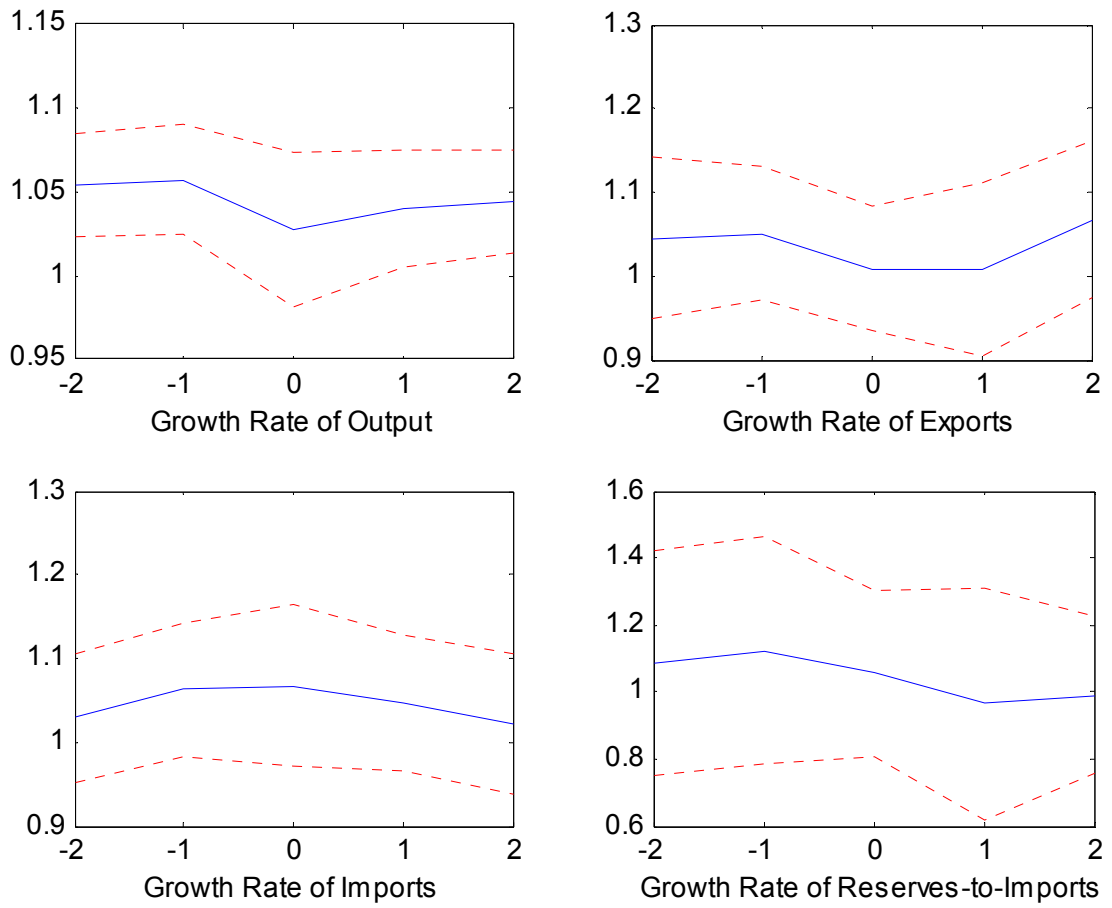

Figure 4: Impact of a Natural Disaster in the Sahel
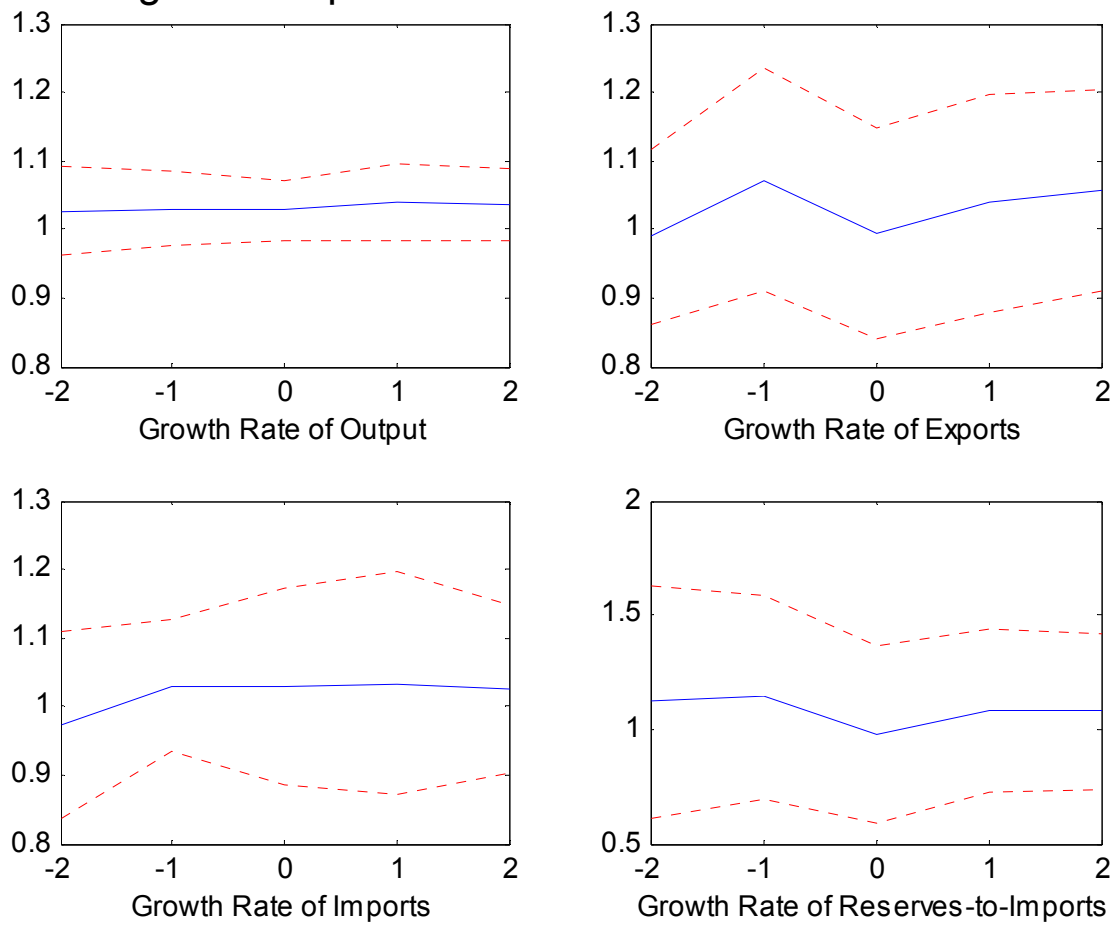
Figure 5: The Optimal Reserves-to-Imports ratio in the Caribbean: Sensitivity Analysis
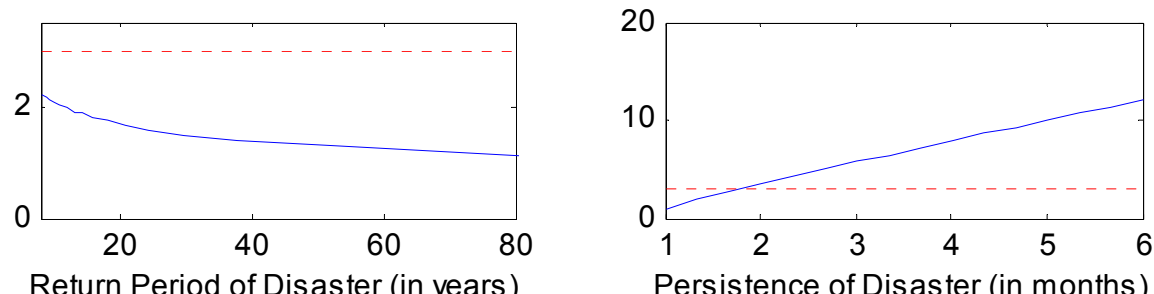

Persistence of Disaster (in months)
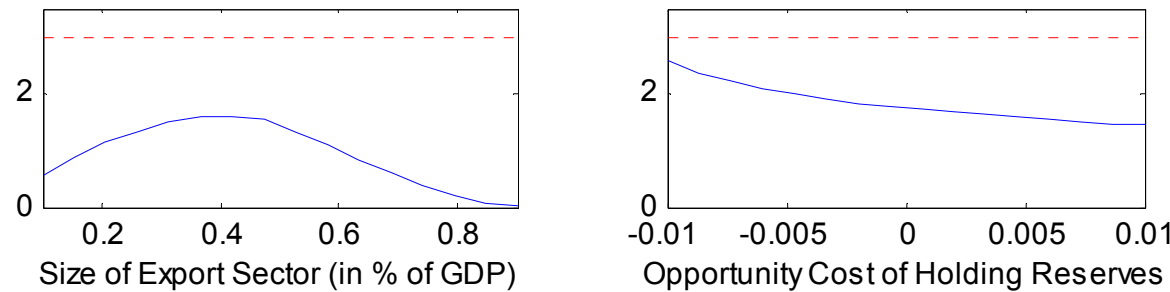

Size of Export Sector (in \% of GDP)
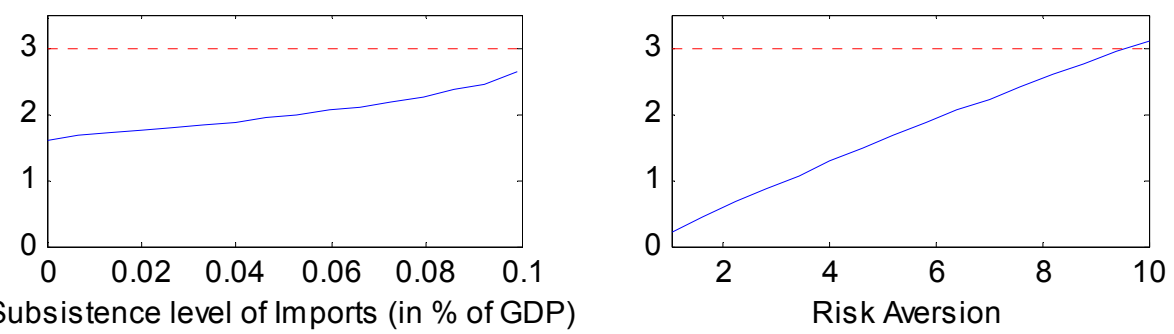

Figure 6: The Optimal Reserves-to-Import ratio in the Sahel: Sensitivity Analysis
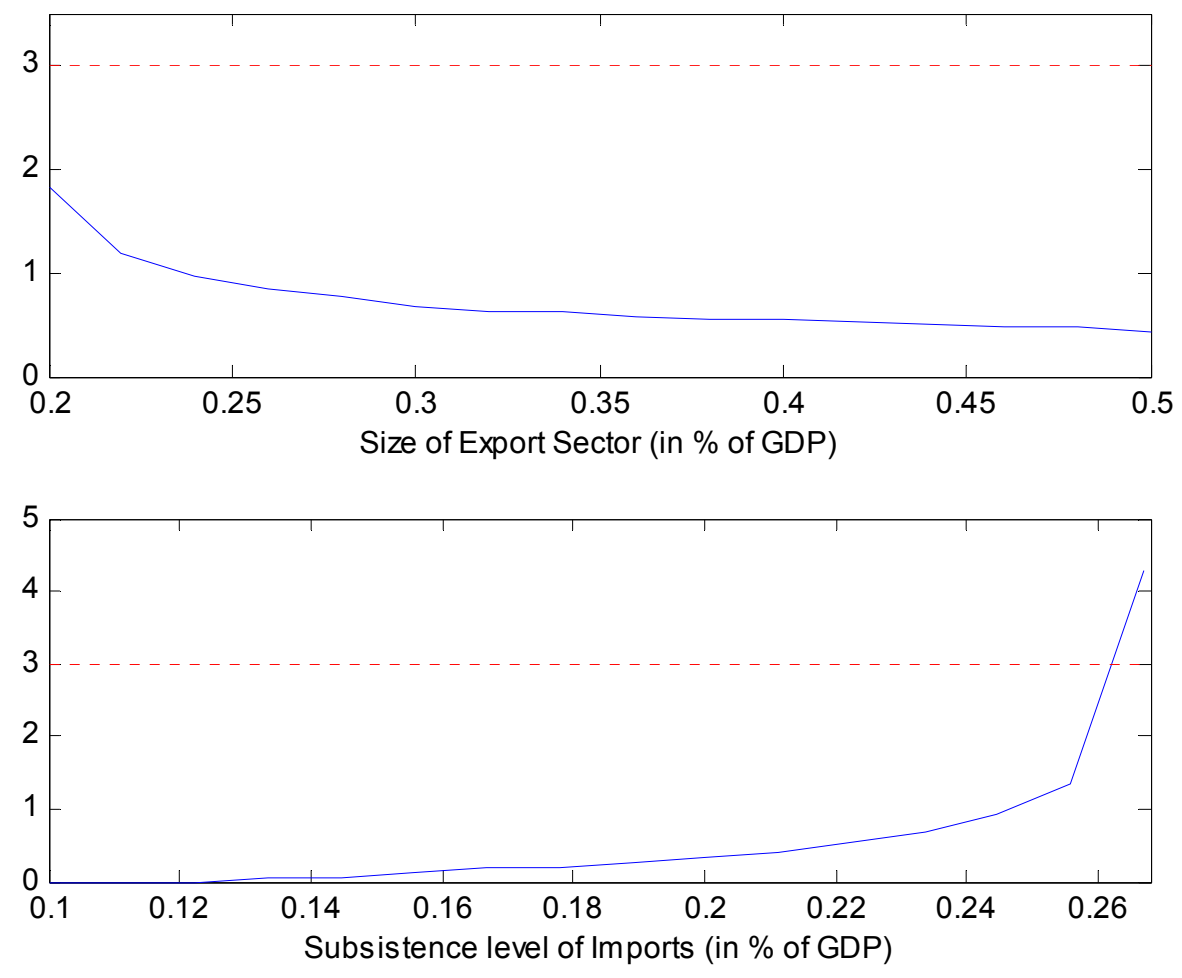
Figure 7a: Impact of external shocks in the Caribbean (in years)
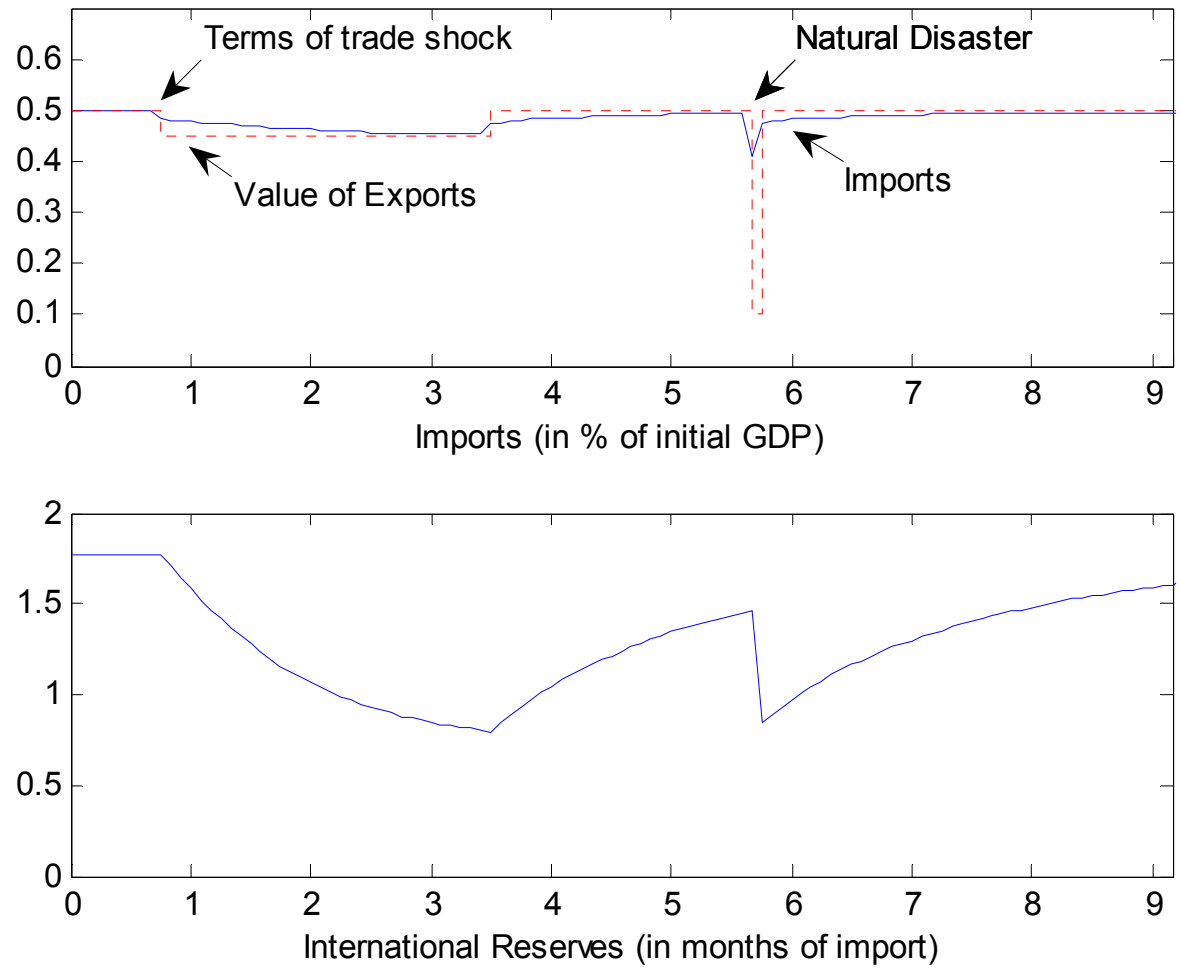

Figure 7b: Impact of external shocks in the Sahel (in years)
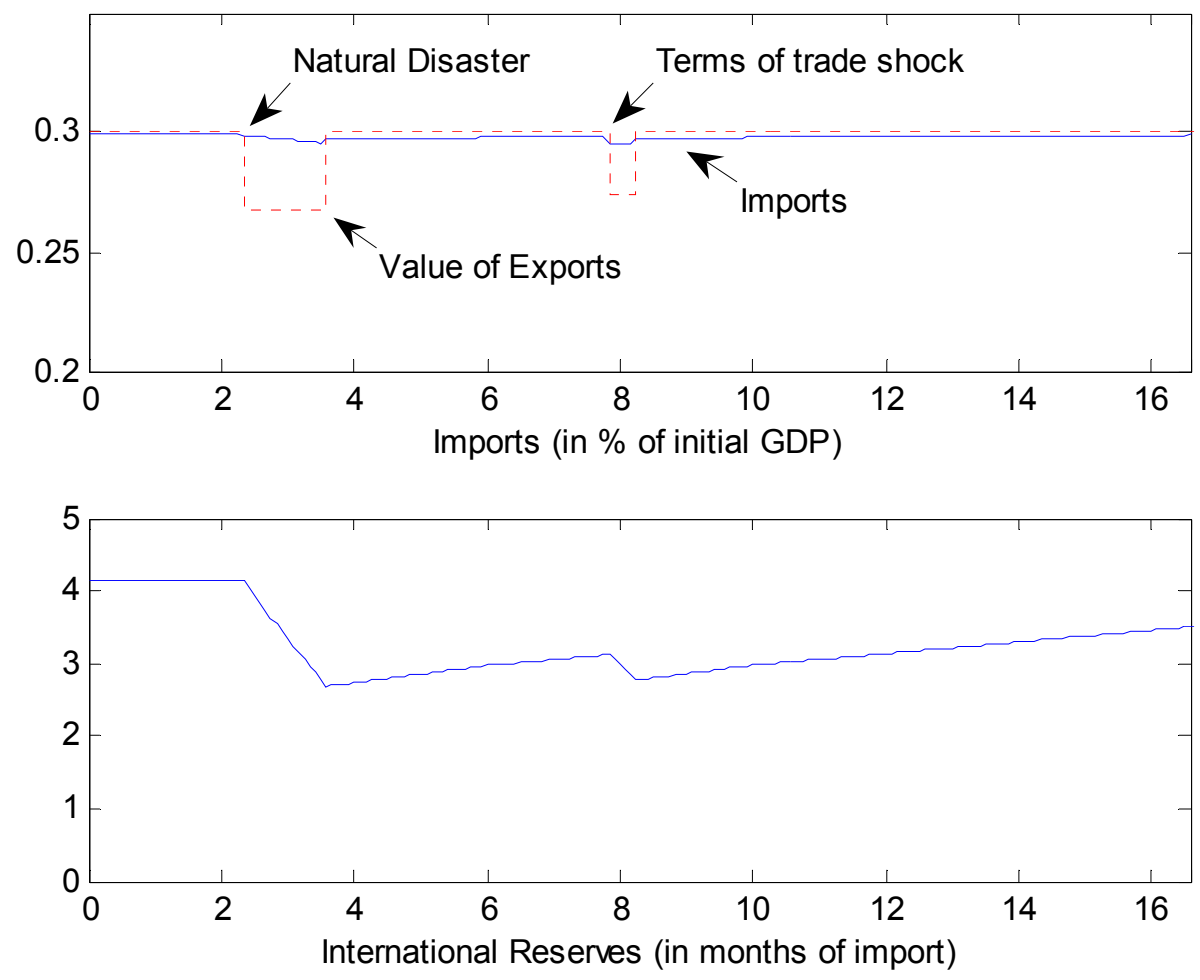
APPENDIX I. LIST OF COUNTRIES IN EACH GROUP.

\begin{tabular}{cc}
\hline Caribbean & Sahel \\
\hline Antigua and Barbuda & Benin \\
The Bahamas & Burkina Faso \\
Barbados & Cape Verde \\
Belize & Cote d'Ivoire \\
Dominica & The Gambia \\
Dominican Republic & Guinea \\
Grenada & Guinea Bissau \\
Haiti & Mali \\
Honduras & Mauritania \\
Jamaica & Niger \\
St. Kitts and Nevis & Senegal \\
St. Lucia & Sierra Leone \\
St. Vincent and Grenadines & Togo \\
Trinidad and Tobago &
\end{tabular}

